\title{
“¡Vivan los indios argentinos!”. Los ranqueles ante la etnificación discursiva en la frontera de guerra hacia 1870
}

"Long Life to the Argentine Indians!" Ranqueles and discursive ethnization discourse at the war frontier by 1870

\section{Axel César Lazzari}

\section{(2) OpenEdition}

\section{Journals}

\section{Electronic version}

URL: http://journals.openedition.org/corpusarchivos/1097

DOI: 10.4000/corpusarchivos.1097

ISSN: 1853-8037

\section{Publisher}

Diego Escolar

\section{Electronic reference}

Axel César Lazzari, « "Vivan los indios argentinos!". Los ranqueles ante la etnificación discursiva en la frontera de guerra hacia 1870 », Corpus [En línea], Vol 2, No 1 | 2012, Publicado el 30 junio 2012, consultado el 06 mayo 2019. URL : http://journals.openedition.org/corpusarchivos/1097 ; DOI : 10.4000/corpusarchivos.1097

This text was automatically generated on 6 May 2019.

Licencia Creative Commons: Atribución-NoComercial 2.5 Argentina (CC BY-NC 2.5 AR) 


\section{“¡Vivan los indios argentinos!”. Los ranqueles ante la etnificación discursiva en la frontera de guerra hacia 1870}

"Long Life to the Argentine Indians!" Ranqueles and discursive ethnization

discourse at the war frontier by 1870

Axel César Lazzari

\section{EDITOR'S NOTE}

DIRECTOR: Joao Pacheco de Oliveira Fihlo

GRADO: MAESTRIA EN ANTROPOLOGIA SOCIAL

INSTITUCION: Programa de Posgraduación en Antropología Social del Museu Nacional, Universidade Federal do Rio de Janeiro.

FECHA DE DEFENSA: marzo 2006

CIUDAD: Rio de Janeiro, Brasil

CONICET-IDAES, Universidad Nacional de San Martín

2 Correo electrónico: axellazzari@hotmail.com 


\section{ABSTRACTS}

"Long Life to the Argentine Indians!" How can we understand this salutation from a military officer to a group of Rankülche Indian horseriders while "visiting" their territory as a diplomatic agent during March 1870? Was there an ideological code already shared that made it possible to conflate "Indian" and "Argentine" and translate them into "Ranquel"? ¿What were the stakes in this salute by Col. Lucio V. Mansilla? In this study the argument is made that categories such as "Argentine Indian" are part of discursive strategies which construct the Ranquel as ethnic aliens of the nation thus becoming hegemonic mechanisms of ethnization. The problem of ethnization of the Ranquel Indians is anaylized in two-steps. Framing the situation of 1870 as an historical effect, structures of long duration are reconstructed from the perspective of nation-state building at the frontier, describing the patterns of economic, political and cultural interdependence of Indians and Hispanic-creoles from mid- $16^{\text {th }}$ to late $19^{\text {th }}$ centuries in the vast territory of Pampa-Araucanía. Secondly, I analize the discursive strategies of ethnization developed during the 1870 treaty negotiations between the military-missionary expeditioners and the Ranquel, higlighting their textual, intertextual and interdiscursive aspects as well as identifying the similarities and differences among the discursives styles of the military, the missionary and the "montonero" refugees in Indian territory. Likewise, it is hoped to accomplish the general purpose of this study which is to describe and explain the hegemonic logics of ethnization of the Ranquel Indians as a triple effect of historical process, social situation and discursive strategy.

“¡Vivan los indios argentinos!”: ¿cómo entender este saludo de un militar a un grupo de recelosos jinetes ranqueles mientras "excursionaba" en misión diplomática a Tierra Adentro hacia marzo de 1870? ¿Existía ya un código ideológico compartido por el cual "indio” y "argentino" pudieran combinarse y ser traducibles con el gentilicio "ranquel”? ¿Qué estaba en juego en esta interpelación lanzada por el Coronel Lucio V. Mansilla? Este estudio desarrolla el argumento de que categorías como "indio argentino" son parte de estrategias discursivas que construyen a los ranqueles como otredades étnicas subordinadas a la nación y, en tanto tales, pueden ser abordadas como mecanismos hegemónicos de etnización. El problema de la etnización de los ranqueles es analizado en dos tiempos. En un primer movimiento, se aborda la situación de 1870 como un efecto histórico y se reconstruyen las estructuras de larga duración desde la perspectiva de la formación del estado-nación en la frontera, describiendo los patrones de interdependencia económica, política, y cultural entre indígenas e hispanocriollos desde mediados del siglo XVI hasta fines XIX en el amplio territorio de Pampa-Araucanía. En un segundo momento, se estudian las estrategias discursivas de etnización desarrolladas en la situación de negociación del tratado de 1870 entre la comitiva militar-misionera y los ranqueles, profundizando en su textualidad, intertextualidad e interdiscursividad y estableciendo diferencias y semejanzas entre los estilos discursivos del ejército, la misión religiosa y las milicias montoneras. De este modo, se espera cumplir el propósito de caracterizar y explicar la lógica hegemónica de la etnización de los ranqueles atendiendo a la triple mediación del proceso histórico, la situación social y el discurso como estrategia. 
INDEX

Palabras claves: estrategias discursivas de etnización, ranqueles, frontera, siglo XIX

Keywords: discursive strategies of ethnization, Ranquel Indians, frontier, 19th century 